Widya Akuntansi dan Keuangan

Universitas Hindu Indonesia

Edisi Agustus 2019, ISSN 2655-9498

\title{
PENDAPATAN PEDAGANG PASAR SENI GUWANG: KAJIAN BERDASARKAN FAKTOR INTERNAL DAN EKSTERNAL
}

\author{
Ida Ayu Nyoman Yuliastuti ${ }^{1)}$ \\ Ni Luh Putu Sandrya Dewi ${ }^{2)}$ \\ 1),2)Universitas Mahasaraswati Denpasar,email: ia.yuliastuti@unmas.ac.id
}

\begin{abstract}
One of the famous art markets in Gianyar Regency is the Guwang Art Market. Along with the development of globalization and competition in the economy, the economic potential of the Guwang Art Market has gradually experienced sluggishness. The Gianyar Regency Government as the manager of the Guwang Art Market and the Guwang Art Market traders must pay attention to internal and external factors that can increase tourist visits to the Guwang Art Market. This study aims to conduct a more in-depth analysis of internal and external factors that can affect the income of the Guwang Art Market traders.

The sample in this study consisted of 84 traders from 540 traders in the Guwang Sukawati Art Market, Gianyar Regency. Secondary data was obtained from the Guwang Art Market Administration Office and the primary data was obtained by distributing questionnaires to the Guwang Art Market traders. The analysis technique used is multiple linear regression analysis techniques.
\end{abstract}

Keywords: art market, merchant income, business capital, length of business, working hours, business location, parking, counseling and training.

\section{PENDAHULUAN}

Persaingan dan perkembangan dunia usaha semakin kuat dan tajam sehingga untuk meningkatkan usaha diperlukan penanganan yang serius dari setiap usaha untuk dapat bersaing dengan usaha lainnya. Kemampuan usaha dalam menghasilkan kuntungan merupakan faktor penting bagi suatu usaha dapat bertahan dan berkembang lebih besar (Putra dan Yuliastuti, 2019). Untuk memperoleh keuntungan tersebut maka Usaha Mikro Kecil dan Menengah (UMKM) yang terdapat di pasar seni tradisional harus dapat bersaing dengan pasar seni modern lainnya yang saat ini sudah semakin banyak jumlahnya. Pasar seni tradisional merupakan target pemasaran dari produk yang dihasilkan oleh Usaha Mikro Kecil dan Menengah (UMKM) yang bergerak dalam bidang industri kecil dan kerajinan tangan (Bali Post, 2013). Daerah dituntut untuk berperan aktif dalam mengoptimalkan penerimaan pendapatan daerahnya (Yuliastuti dan 
Dewi, 2017. Salah satu daerah di Bali yaitu Kabupaten Gianyar merupakan daerah yang paling banyak memiliki pasar seni tradisional yaitu berjumlah 7 (tujuh) pasar seni tradisional yang dikelola langsung oleh Desa Adat maupun dikelola oleh Pemerintah Kabupaten Gianyar yang dapat menampung 1.866 pedagang (Bali Post, 2013). Salah satu pasar seni yang terkenal di Kabupaten Gianyar selain Pasar Seni Sukawati adalah Pasar Seni Guwang.

Pasar Seni Guwang memiliki tempat parkir yang luas, tertata rapi dan lebih sejuk karena di tengah-tengah pasarnya terdapat jalan dan pohon-pohon pembatas, sehingga wisatawan biasanya akan lebih leluasa berbelanja dan memilih barang-barang yang ditawarkan. Seiring perkembangan globalisasi dan persaingan dalam perekonomian, potensi ekonomis yang dimiliki Pasar Seni Guwang mengalami kelesuan, karena adanya pasar oleh-oleh modern yang menjual produk kerajinan seperti di Pasar Seni Guwang. Salah satu keunggulan pasar oleholeh modern saat ini yang tidak dimiliki Pasar Seni Guwang adalah proses transaksi jual-beli secara online melalui internet, serta servis dan fee yang memuaskan bagi para pemandu wisata.

Tabel 1. Jumlah Kedatangan Bus dan Tamu di Pasar Seni Guwang

\begin{tabular}{|l|c|c|c|c|}
\hline \multirow{2}{*}{ Bulan } & \multicolumn{2}{|c|}{ Tahun 2015 } & \multicolumn{2}{c|}{ Tahun 2016 } \\
\cline { 2 - 5 } & Bus (Unit) & Wisatawan (Orang) & Bus (Unit) & Wisatawan (Orang) \\
\hline Januari & 791 & 31640 & 583 & 23320 \\
\hline Februari & 556 & 22240 & 403 & 16120 \\
\hline Maret & 815 & 32600 & 700 & 28000 \\
\hline April & 947 & 37880 & 951 & 38040 \\
\hline Mei & 1286 & 51440 & 1041 & 41640 \\
\hline Juni & 390 & 15600 & 124 & 4960 \\
\hline Juli & 201 & 8040 & 338 & 13520 \\
\hline Agustus & 477 & 19080 & 341 & 13640 \\
\hline September & 276 & 11640 & 227 & 9080 \\
\hline Oktober & 625 & 25000 & 497 & 1737 \\
\hline Nopember & 494 & 19760 & 363 & 14520 \\
\hline Desember & 982 & 39280 & 883 & 35320 \\
\hline TOTAL & $\mathbf{7 8 4 0}$ & $\mathbf{3 1 3 6 0 0}$ & $\mathbf{6 4 5 1}$ & $\mathbf{2 5 8 0 4 0}$ \\
\hline
\end{tabular}

Sumber: Kantor Administrasi Pasar Seni Guwang Kabupaten Gianyar, 2017 
Widya Akuntansi dan Keuangan

Universitas Hindu Indonesia

Edisi Agustus 2019, ISSN 2655-9498

Tabel 1 di atas menunjukkan bahwa total kedatangan bus dan wisatawan pada tahun 2015 sebanyak 7.840 bus dengan wisatawan sebanyak 313.600 orang dan mengalami penurunan pada tahun 2016 yaitu menjadi 6.451 bus dengan wisatawan sebanyak 258.040 orang. Kondisi ini sangat meresahkan pedagang di Pasar Seni Guwang dan menganggap pasar oleh-oleh modern sebagai pesaing utama yang menyebabkan menurunnya omzet penjualan yang berdampak kepada menurunnya tingkat pendapatan pedagang Pasar Seni Guwang secara drastis.

Mengantisipasi ekspansi dari pasar oleh-oleh modern di Kabupaten Gianyar maka Pemerintah Kabupaten Gianyar dalam hal ini sebagai pengelola Pasar Seni Guwang serta para pedagang Pasar Seni Guwang harus memperhatikan faktor internal dan eksternal yang dapat meningkatkan kunjungan wisatawan ke Pasar Seni Guwang. Beberapa faktor internal seperti modal usaha, lama usaha, jam kerja dan faktor eksternal seperti lokasi usaha, fasilitas parkir, penyuluhan dan pelatihan merupakan beberapa faktor penting yang dapat mempengaruhi wisatawan untuk berkunjung ke Pasar Seni Guwang.

\section{Pengaruh Modal Usaha Terhadap Pendapatan Pedagang Pasar Seni Guwang}

Faktor modal adalah faktor yang mempengaruhi pendapatan pedagang karena semakin banyak modal yang dimiliki pedagang maka akan semakin besar juga pendapatannya (Atun, 2016). Peningkatan jumlah modal yang digunakan sehingga dengan jumlah modal yang lebih besar diharapkan terjadi peningkatan jumlah penambahan bahan produksi guna menghasilkan output barang dagangan yang diperdagangkan, sehingga meningkatkan pendapatan (Wahyudi, 2010). Semakin besar modal atau faktor produksi yang dimiliki maka probabilitas pendapatan yang diterima pedagang akan semakin tinggi (Artaman, 2015). Penelitian berkaitan dengan modal usaha diperkuat oleh penelitian yang dilakukan oleh Wahyudi (2010), Firdausa (2012), Artaman (2015) dan Atun (2016). Berdasarkan penjelasan tersebut, maka hipotesis yang digunakan dalam penelitian ini adalah: 
Widya Akuntansi dan Keuangan

Universitas Hindu Indonesia

Edisi Agustus 2019, ISSN 2655-9498

$\mathrm{H}_{1} \quad$ : Modal usaha berpengaruh positif terhadap pendapatan pedagang Pasar Seni Guwang

\section{Pengaruh Lama Usaha Terhadap Pendapatan Pedagang Pasar Seni Guwang}

Lama usaha memegang peranan penting dalam proses melakukan usaha perdagangan. Lama pembukaan usaha dapat mempengaruhi tingkat pendapatan, lama seorang pelaku bisnis menekuni bidang usahanya akan mempengaruhi produktivitasnya sehingga dapat menambah efisiensi dan menekan biaya produksi lebih kecil daripada penjualan (Firdausa, 2012). Semakin lama menekuni bidang usaha perdagangan akan makin meningkatkan pengetahuan tentang selera dan perilaku konsumen (Artaman, 2015). Berdasarkan uraian diatas maka hipotesis yang dikembangkan dalam penelitian ini adalah:

$\mathrm{H}_{2} \quad$ : Lama usaha berpengaruh positif terhadap pendapatan pedagang Pasar Seni Guwang

\section{Pengaruh Jam Kerja Terhadap Pendapatan Pedagang Pasar Seni Guwang}

Jam kerja atau jam buka kios pedagang Pasar Seni Guwang sangat mempengaruhi jumlah tamu yang terlayani karena pembeli tidak pasti jam kedatangannya. Faktor jam kerja pedagang secara teoritis mempengaruhi pendapatan usaha dimana semakin tinggi waktu yang digunakan dalam bekerja/ buka kios maka probabilitas pendapatan yang diterima pedagang sektor informal akan semakin tinggi (Firdausa, 2012). Penelitian yang dilakukan oleh Wahyudi (2010) menunjukkan bahwa jam kerja mempunyai pengaruh signifikan positif terhadap besarnya pendapatan pedagang pasar tradisional. Berdasarkan uraian diatas, maka hipotesis yang digunakan dalam penelitian ini adalah:

$\mathrm{H}_{3} \quad$ : Jam kerja berpengaruh positif terhadap pendapatan pedagang Pasar Seni Guwang

\section{Pengaruh Lokasi Usaha Terhadap Pendapatan Pedagang Pasar Seni Guwang}

Merencanakan suatu usaha perlu memilih letak lokasi usaha yang strategis untuk mudah dijangkau konsumen. Berdasarkan teori dan penelitian sebelumnya menyatakan bahwa dengan lokasi atau letak yang strategis dari jangkauan konsumen meliputi transportasi, lokasi penjualan, dan jarak antara lokasi toko dengan rumah dapat mempengaruhi pendapatan pedagang. Penentuan lokasi juga 
sangat mempengaruhi pendapatan. Semakin strategis lokasi berdagang yang ditempatinya maka probabilitas pendapatan yang diterima pedagang akan semakin tinggi pula. Penelitian ini diperkuat oleh Artaman (2015) dan Atun (2016). Hasil penelitian yang dilakukan Artaman (2015) dan Atun (2016) sama-sama menunjukkan bahwa lokasi usaha berpengaruh positif terhadap pendapatan pedagang baik secara parsial dan simultan. Berdasarkan uraian diatas maka hipotesis yang dikembangkan dalam penelitian ini adalah:

$\mathrm{H}_{4} \quad$ : Lokasi usaha berpengaruh positif terhadap pendapatan pedagang Pasar Seni Guwang

\section{Pengaruh Parkir Terhadap Pendapatan Pedagang Pasar Seni Guwang}

Fasilitas parkir merupakan fasilitas pelayanan umum dan merupakan faktor sangat penting dalam sistem transportasi di daerah perkotaan. Pasar Seni Guwang saat ini sudah memiliki lahan parkir yang luas, untuk itu diperlukan suatu kajian lebih lanjut apakah dengan adanya lahan parkir yang luas tersebut akan berdampak pada peningkatan kunjungan wisatawan, sehingga pendapatan para pedagang Pasar Seni Guwang meningkat. Penelitian ini semakin diperkuat dengan adanya penelitian dari Artaman (2015) yang menunjukkan bahwa secara simultan variabel modal usaha, lama usaha, jam kerja, parkir dan lokasi usaha berpengaruh signifikan terhadap pendapatan pedagang Pasar Seni Guwang. Berdasarkan uraian diatas maka hipotesis yang dikembangkan dalam penelitian ini adalah:

$\mathrm{H}_{5} \quad$ : Parkir berpengaruh positif terhadap pendapatan pedagang Pasar Seni Guwang Pengaruh Penyuluhan dan Pelatihan Terhadap Pendapatan Pedagang Pasar Seni Guwang

Penyuluhan dan pelatihan merupakan keterlibatan seseorang untuk melakukan kegiatan belajar dan praktik secara berulang-ulang dan terus-menerus dengan komunikasi informasi secara sadar dengan tujuan untuk meningkatkan kemampuan dalam membuat keputusan yang benar. Dalam kegiatan penyuluhan dan pelatihan terjadi proses transfer ilmu pengetahuan dan teknologi kepada para pedagang sehingga mendorong terjadinya perubahan dalam diri pedagang. Perubahan yang diharapkan tercapai dalam kegiatan penyuluhan dan pelatihan mencakup perubahan pengetahuan, sikap dan keterampilan para pedagang untuk dapat meningkatkan pendapatannya. Dari wawancara singkat yang dilakukan diketahui bahwa beberapa pedagang Pasar Seni Guwang pernah mengikuti penyuluhan dan pelatihan, 
Widya Akuntansi dan Keuangan

Universitas Hindu Indonesia

Edisi Agustus 2019, ISSN 2655-9498

sehingga peneliti tertarik untuk meneliti apakah ada pengaruh antara penyuluhan dan pelatihan yang pernah didapat oleh para pedagang dengan pendapatan yang diperolehnya. Berdasarkan uraian diatas maka hipotesis yang dikembangkan dalam penelitian ini adalah:

$\mathrm{H}_{6} \quad$ : Penyuluhan dan pelatihan berpengaruh positif terhadap pendapatan pedagang Pasar Seni Guwang.

\section{METODE PENELITIAN}

Penelitian ini dilakukan di Pasar Seni Guwang Kabupaten dan obyek dalam penelitian ini adalah pedagang-pedagang Pasar Seni Guwang Kabupaten Gianyar, serta bertujuan untuk mencari bukti empiris mengenai penyebab perubahan pendapatan pedagang Pasar Seni Guwang, yaitu faktor internal dan eksternal. Data yang digunakan adalah data primer (kuesioner) dan data sekunder. Langkah selanjutnya adalah pengujian hipotesis dengan menggunakan alat bantu SPSS melalui analisis regresi linear berganda. Hipotesis akan diuji secara parsial dan simultan.

Penelitian ini adalah penelitian kuantitatif dengan bentuk eksplanasi asosiatif yang menekankan pada beberapa variabel yang bertujuan menguji teori dan menegakan fakta-fakta untuk memperoleh hipotesis atas suatu penelitian (Sugiyono, 2013). 


\section{Gambar 1. Kerangka Pemikiran}

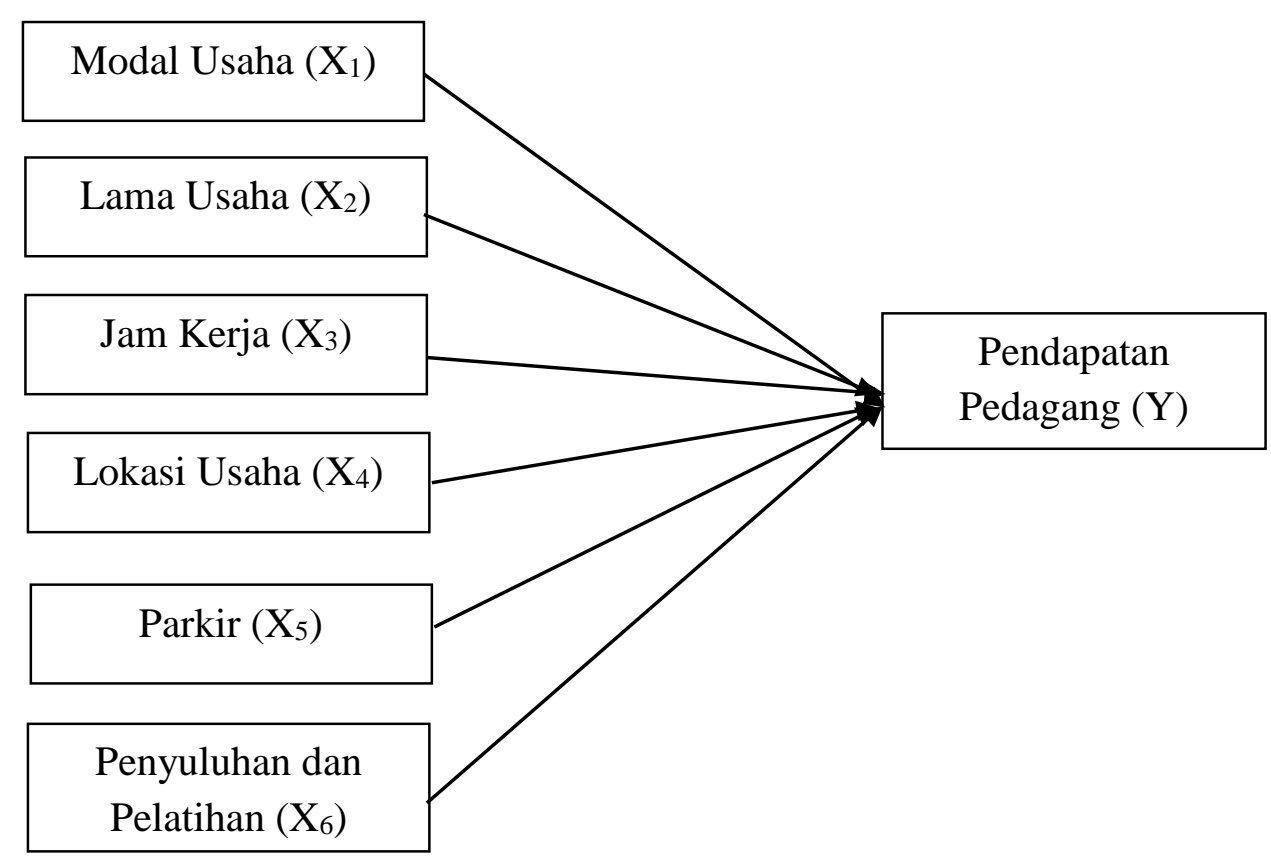

Sumber: Hasil pemikiran peneliti (2019)

Populasi dalam penelitian ini adalah seluruh pedagang Pasar Seni Guwang yang berjumlah 540 pedagang. Dalam penelitian ini digunakan rumus Slovin dengan titik kritis 10 persen untuk menentukan jumlah sampel:

$$
\begin{aligned}
& n=\frac{N}{N(d)^{2}+1} \\
& \mathrm{n}=\frac{540}{=84,37 \approx 84} \\
& 540(0,1)^{2}+1
\end{aligned}
$$

Keterangan:

$$
\begin{aligned}
& \mathrm{n}=\text { Ukuran sampel } \\
& \mathrm{N}=\text { Ukuran populasi } \\
& \mathrm{d}=\text { Standar error }(10 \%)
\end{aligned}
$$

Berdasarkan rumusan di atas, jumlah sampel yang digunakan dalam penelitian ini terdiri dari 84 pedagang Pasar Seni Guwang. Penentuan jumlah sampel responden dilakukan secara 
acak tanpa memperhatikan strata yang ada dalam populasi. Hal ini dilakukan karena anggota populasi bersifat homogen.

Teknik Analisis Data dalam penelitian ini menggunakan uji asumsi klasik, yaitu uji normalitas, uji multikolinieritas, dan uji heteroskedastisitas. Tahap berikutnya adalah melakukan analisis regresi linear berganda untuk mengetahui atau memperoleh gambaran mengenai pengaruh variabel independen pada variabel dependen. Persamaan model regresi linear berganda dengan persamaan sebagai berikut:

$$
Y=\alpha+\beta_{1} X_{1}+\beta_{2} X_{2}+\beta_{3} X_{3}+\beta_{4} X_{4}+\beta_{5} X_{5}+\beta_{6} X_{6}+e
$$

\section{Keterangan:}

$\mathrm{Y}=$ Pendapatan pedagang

$\mathrm{X}_{1}=$ Modal usaha

$\mathrm{X}_{2}=$ Lama usaha

$\mathrm{X}_{3}=$ Jam kerja

$\mathrm{X}_{4}=$ Lokasi usaha

$\mathrm{X}_{5}=$ Parkir

$\mathrm{X}_{6}=$ Penyuluhan dan Pelatihan

$\alpha=$ konstanta

$\mathrm{e}=$ variabel pengganggu

\section{HASIL DAN PEMBAHASAN}

Berikut ini adalah hasil penelitian dan pembahasan dari uji statistik deskriptif, uji asumsi klasik, serta hasil pengujian hipotesis melalui analisis regresi linear berganda.

\section{Tabel 2. Statistik Deskriptif}

\begin{tabular}{|l|r|r|r|r|r|}
\hline \multicolumn{1}{|c|}{ Descriptive Statistics } \\
\hline MODAL & N & Minimum & Maximum & \multicolumn{1}{|c|}{ Mean } & Std. Deviation \\
LAMA & 84 & 2,00 & 50,00 & 12,8214 & 11,00456 \\
JMK & 84 &, 50 & 20,00 & 9,2024 & 5,42313 \\
LOKASI & 84 & 156,00 & 286,00 & 233,3214 & 24,91729 \\
PARKIR & 84 & 1,00 & 4,00 & 3,3929 &, 94446 \\
PP & 84 & 4,00 & 20,00 & 17,1667 & 2,44374 \\
PEND & 84 &, 00 & 1,00 &, 2381 &, 42848 \\
Valid N (listwise) & 84 &, 64 & 78,00 & 8,3332 & 1,80845 \\
\hline
\end{tabular}

Sumber: data diolah, 2019

Tabel 2 di atas menunjukkan bahwa variabel modal memiliki nilai mean 12,8214 yang berarti bahwa modal dari pedagang pasar selama tahun 2018 adalah 1282,14 persen dengan 
standar deviasi sebesar 11,00456 atau 1100,46 persen. Rata-rata hitung (mean) lama pembukaan usaha dari pedagang pasar adalah sebesar 9,2024 yang berarti bahwa persentase lama pembukaan usaha sebesar 920,24 persen dengan standar deviasi sebesar 5,42313 atau 542,31 persen. Nilai rata-rata untuk jam kerja adalah 233,3214 atau 23332,14 persen dengan nilai standar deviasi sebesar 24,91729 atau 2491,73 persen. Sedangkan, lokasi usaha menunjukkan nilai rata-rata sebesar 3,3929 atau 339,3 persen, dengan standar deviasi sebesar 0,94446 atau 94,45 persen. Nilai rata-rata parkir adalah 17,1667 atau 1716,67 persen dan standar deviasi sebesar 2,44374 atau 233,37 persen. Penyuluhan dan pelatihan menujukkan nilai rata-rata sebesar 0,2381 atau 23,81 persen dengan standar deviasi sebesar 0,42848 atau 42,85 persen. Sedangkan, nilai rata-rata pendapatan adalah 8,3332 atau 833,32. Hal ini menunjuka bahwa pendapatan pedagang selama tahun 2018 adalah 833,32 persen persen dengan standar deviasi sebesar 11,80845 atau 1180,85 persen.

\section{Tabel 3. Uji Normalitas Data}

One-Sample Kolmogorov-Smirnov Test

\begin{tabular}{|ll|r|}
\hline & & \multicolumn{1}{c|}{$\begin{array}{c}\text { Unstandardiz } \\
\text { ed Residual }\end{array}$} \\
\hline Normal Parametersa,b & Mean & 84 \\
& Std. Deviation &, 0000000 \\
Most Extreme & Absolute &, 91086457 \\
Differences & Positive &, 053 \\
Kolmogorov-Smirnov Z & Negative &, 053 \\
Asymp. Sig. (2-tailed) & &,- 046 \\
\hline
\end{tabular}

a. Test distribution is Normal.

b. Calculated from data.

Sumber: data diolah, 2019

Hasil uji normalitas data sesuai dengan Tabel 3 di atas yang menunjukkan nilai Kolmogorov-Smirnov $\mathrm{Z}$ adalah 0,486 dengan nilai signifikansi sebesar 0,972. Hal ini berarti variabel menunjukkan data berdistribusi secara normal. 
Widya Akuntansi dan Keuangan

Universitas Hindu Indonesia

Edisi Agustus 2019, ISSN 2655-9498

Tabel 4. Uji Multikolinieritas

\begin{tabular}{|l|l|l|}
\hline \multicolumn{1}{|c|}{ Model } & \multicolumn{2}{|c|}{ Collinearity Statistics } \\
\cline { 2 - 3 } & Tolerance & VIF \\
\hline MODAL & 0,970 & 1,031 \\
LAMA & 0,959 & 1,043 \\
JMK & 0,930 & 1,075 \\
LOKASI & 0,920 & 1,087 \\
PARKIR & 0,952 & 1,051 \\
PP & 0,956 & 1,046 \\
& & \\
\hline
\end{tabular}

Sumber: data diolah, 2019

Hasil uji multikolinearitas pada Tabel 4 di atas menunjukkan bahwa nilai VIF pada keenam variabel bebas memiliki nilai dibawah angka 10 dan nilai tolerance untuk keenam variabel bebas tersebut menunjukkan nilai di atas 0,10 . Sehingga, multikolinearitas tidak terjadi di antara variabel bebas.

\section{Tabel 5. Uji Heteroskedastisitas}

Coefficients

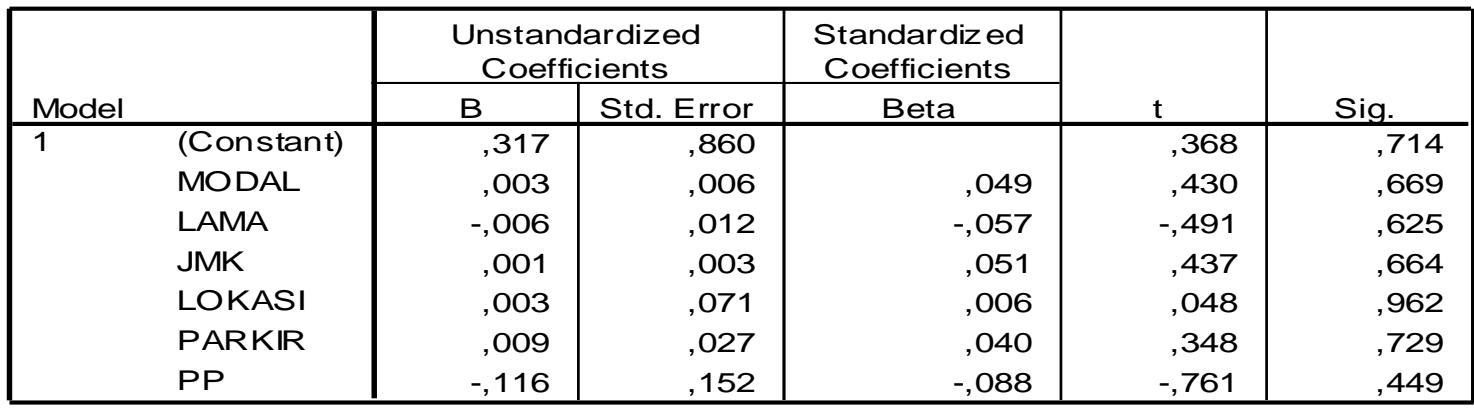

a. Dependent Variable: ABRES

Sumber: data diolah, 2019

Hasil uji heterokedasitas pada Tabel 5 penelitian ini menunjukkan bahwa nilai signifikansi untuk keenam variabel bebas berada di atas 0,05 . Sehingga, keenam variabel tidak mengalami gejala heterokedastisitas. 
Tabel 6. Analisis Regresi Linear Berganda

\begin{tabular}{|c|c|c|c|c|c|c|c|c|}
\hline \multicolumn{9}{|c|}{ Coefficients } \\
\hline \multirow{2}{*}{\multicolumn{2}{|c|}{ Model }} & \multicolumn{2}{|c|}{$\begin{array}{c}\text { Unstandardized } \\
\text { Coefficients }\end{array}$} & \multirow{2}{*}{$\begin{array}{c}\text { Standardized } \\
\text { Coefficients } \\
\text { Beta }\end{array}$} & \multirow[b]{2}{*}{$t$} & \multirow[b]{2}{*}{ Sig. } & \multicolumn{2}{|c|}{ Collinearity Statistics } \\
\hline & & $\mathrm{B}$ & Std. Error & & & & Tolerance & VIF \\
\hline \multirow[t]{7}{*}{1} & (Constant) & $-1,820$ & 1,397 & & $-1,302$ & , 197 & & \\
\hline & MODAL & 037 &, 010 & ,391 & 3,867 & ,000 & ,970 & 1,031 \\
\hline & LAMA & ,024 & ,020 & ,124 & 1,223 & ,225 & ,959 & 1,043 \\
\hline & JMK & ,007 & ,004 & , 169 & 1,639 & , 105 & ,930 & 1,075 \\
\hline & LOKASI &,- 050 &, 115 &,- 045 &,- 432 &, 667 & ,920 & 1,087 \\
\hline & PARKIR & ,068 &, 044 & , 160 & 1,565 & ,122 & ,952 & 1,051 \\
\hline & $\mathrm{PP}$ &,- 019 & ,248 &,- 008 &,- 077 & ,939 & ,956 & 1,046 \\
\hline
\end{tabular}

a. Dependent Variable: LN_PEND

Sumber: data diolah, 2019

Hasil analisis regresi linear berganda pada Tabel 6 menunjukkan bahwa rumusan persamaan dapat disusun sebagai berikut ini:

$$
Y=-1,820+0,37 X_{1}+0,024 X_{2}+0,007 X_{3}-0,050 X_{4}+0,068 X_{5}-0,019 X_{6}+e
$$

Persamaan di atas dapat dijelaskan bahwa jika nilai modal, lama usaha, jam kerja, lokasi usaha, parkir dan penyuluhan dan pelatihan sebesar 0 (nol), maka nilai pendapatan pedagang menjadi sebesar -1,820. Apabila modal mengalami kenaikan satu satuan, maka pendapatan pedagang mengalami kenaikan sebesar 0,37 . Begitu pula dengan lama usaha naik satu satuan maka pendapatan pedagang naik sebesar 0,024. Jika jam kerja mengalami kenaikan sebsar satu satuan, maka pendapatan pedagang mengalami peningkatan sebesar 0,007. Berbeda halnya dengan lokasi usaha, jika mengalami kenaikan satu satuan maka pendapatan pedagang mengalami penurunan sebesar 0,050. Apabila, peningkatan satu satuan untuk parkir maka pendapatan pedagang mengalami peningkatan sebesar 0,068 . Sedangkan, jika penyuluhan dan pelatihan kerja mengalami kenaikan sebesar satu satuan, maka pendapatan pedagang mengalami penurunan sebesar 0,019 . 


\section{Tabel 7. Koefisien Determinasi}

\section{Model Summary}

\begin{tabular}{|l|r|r|r|r|}
\hline Model & $\mathrm{R}$ & $\mathrm{R}$ Square & $\begin{array}{c}\text { Adjusted } \\
\mathrm{R} \text { Square }\end{array}$ & $\begin{array}{c}\text { Std. Error of } \\
\text { the Estimate }\end{array}$ \\
\hline 1 &, $487^{\mathrm{a}}$ &, 237 &, 178 &, 94569 \\
\hline
\end{tabular}

a. Predictors: (Constant), PP, JMK, LAMA, MODAL, PARKIR, LOKASI

b. Dependent Variable: LN_PEND

Sumber: data diolah, 2019

Hasil uji kelayakan model pada Tabel 7 di atas menunjukkan bahwa nilai Adjusted $R$ Squeare adalah sebesar 0,178. Artinya, variabel modal usaha $\left(\mathrm{X}_{1}\right)$, lama usaha $\left(\mathrm{X}_{2}\right)$, jam kerja $\left(\mathrm{X}_{3}\right)$, lokasi usaha $\left(\mathrm{X}_{4}\right)$, parkir $\left(\mathrm{X}_{5}\right)$ dan Penyuluhan dan Pelatihan $\left(\mathrm{X}_{6}\right)$ mampu mempengaruhi variabel pendapatan pedagang (Y) sebesar 17,8\% dan sisanya sebesar 82,2\% dipengaruhi oleh variabel lain.

Tabel 8. Uji Kelayakan Model (Uji F)

\begin{tabular}{|c|c|c|c|c|c|c|}
\hline \multicolumn{7}{|c|}{ ANOVA } \\
\hline & & $\begin{array}{l}\text { Sum of } \\
\text { Squares }\end{array}$ & df & Mean Square & $\mathrm{F}$ & Sig. \\
\hline \multirow[t]{3}{*}{1} & Regression & 21,388 & 6 & 3,565 & 3,986 &, $002^{a}$ \\
\hline & Residual & 68,863 & 77 & 894 & & \\
\hline & Total & 90,251 & 83 & & & \\
\hline
\end{tabular}

a. Predictors: (Constant), PP, JMK, LAMA, MODAL, PARKIR, LOKASI

b. Dependent Variable: LN_PEND

Sumber: data diolah, 2019

Uji F pada penelitian ini digunakan untuk mengetahui apakah model regresi layak digunakan unruk mendeskripsikan pengaruh variabel bebas pada variabel terikat. Berdasarkan Tabel 8 di atas menunjukkan bahwa nilai $\mathrm{F}$ hitung adalah 3,986 dengan nilai signifikansi sebesar 0,002 lebih kecil dari taraf nyata signifikansi sebesar 0,05. Hal ini berarti model dalam penelitian ini sudah layak untuk digunakan atau variabel variabel modal usaha $\left(\mathrm{X}_{1}\right)$, lama usaha $\left(\mathrm{X}_{2}\right)$, jam kerja $\left(\mathrm{X}_{3}\right)$, lokasi usaha $\left(\mathrm{X}_{4}\right)$, parkir $\left(\mathrm{X}_{5}\right)$ dan Penyuluhan dan Pelatihan $\left(\mathrm{X}_{6}\right)$, secara simultan mampu mempengaruhi variabel pendapatan pedagang $(\mathrm{Y})$. 
Widya Akuntansi dan Keuangan

Universitas Hindu Indonesia

Edisi Agustus 2019, ISSN 2655-9498

Menurut Ghozali (2012:98), pengujian hipotesis yang dilakukan dengan uji t-test digunakan untuk menunjukkan sejauh mana pengaruh variabel independen secara individual terhadap variabel dependen. Tabel 6 analisis linear berganda di atas menunjukkan bahwa nilai t-hitung sebesar 3,867 dengan nilai signifikansi variabel modal $\left(\mathrm{X}_{1}\right)$ adalah 0,000 berada dibawah nilai 0,05 . Oleh karena itu, variabel modal $\left(\mathrm{X}_{1}\right)$ berpengaruh pada pendapatan pedagang $(\mathrm{Y})$. Semakin tinggi peresentase modal pedagang pasar, maka semakin tinggi pula probabilitas pendapatan yang diterima pedagang pasar. Menurut para pedagang pasar seni Guwang, apabila jumlah modal yang dimiliki meningkat, maka jumlah bahan produksi yang dimiliki juga akan mengalami peningkatan yaitu berupa output barang dagangan yang diperdagangkan, sehingga hal ini tentunya akan meningkatkan pendapatan yang diperolehnya karena dapat menjual barang lebih banyak lagi. Hasil Penelitian ini berkaitan dengan penelitian yang dilakukan oleh Wahyudi (2010), Firdausa (2012), Artaman (2015) dan Atun (2016). Hipotesis satu $\left(\mathrm{H}_{1}\right)$ yaitu Modal usaha berpengaruh positif terhadap pendapatan pedagang Pasar Seni Guwang dapat diterima.

Hasil uji hipotesis dua $\left(\mathrm{H}_{2}\right)$ menunjukkan bahwa nilai t-hitung untuk variabel lama usaha $\left(\mathrm{X}_{2}\right)$ sebesar 1,223 dengan nilai signifikan sebesar 0,225 yang berada di atas nilai 0,05. Hal ini menunjukkan bahwa hipotesis dua $\left(\mathrm{H}_{2}\right)$ yaitu lama usaha berpengaruh positif terhadap pendapatan pedagang Pasar Seni Guwang tidak dapat diterima. Lama tidaknya usaha yang dimiliki oleh pedagang-pedagang pasar seni guwang dirasakan tidak akan dapat menjamin peningkatan pendapatan yang diterima. Hasil penelitian ini tidak dapat mendukung penelitian dari Firdausa (2012) dan Artaman (2015), yang menyatakan lama usaha berpengaruh positif terhadap pendapatan.

Nilai signifikansi untuk variabel jam kerja $\left(\mathrm{X}_{3}\right)$ adalah 0,105 dengan nilai t-hitung sebesar 1,639 , sehingga variabel jam kerja $\left(\mathrm{X}_{3}\right)$ tidak berpengaruh pada pendapatan pedagang (Y). Karena, nilai signifikansinya berada di atas 0,05 . Hipotesis ketiga $\left(\mathrm{H}_{3}\right)$ yaitu Jam kerja berpengaruh positif terhadap pendapatan pedagang Pasar Seni Guwang ditolak. Hasil 
Widya Akuntansi dan Keuangan

Universitas Hindu Indonesia

Edisi Agustus 2019, ISSN 2655-9498

penelitian ini bertolak belakang dengan hasil penelitian Firdausa (2012) dan Wahyudi (2010), yang menyatakan jam kerja berpengaruh positif terhadap pendapatan. Lama tidaknya jam kerja operasional pedagang pasar seni Guwang, tidak akan dapat menjamin peningkatan hasil pendapatan yang diterima oleh pedagang.

Variabel lokasi usaha $\left(\mathrm{X}_{4}\right)$ memiliki nilai t-hitung -0,432 dengan nilai signifikansi sebesar 0,667 yang berada di atas nilai 0,05. Artinya, hipotesis keempat $\left(\mathrm{H}_{4}\right)$ pada penelitian ini adalah lokasi usaha berpengaruh positif terhadap pendapatan pedagang Pasar Seni Guwang tidak dapat diterima. Para pedagang pasar seni guwang berpendapat bahwa lokasi usaha yang dimiliki, baik berada di area depan pasar maupun belakang pasar tidak akan mempengaruhi pendapatan yang diterima. Hal ini karena para wisatawan yang berkunjung biasanya akan melihat-lihat terlebih dahulu produk-produk di setiap kios yang ada di pasar seni guwang sampai ke bagian belakang pasar, setelah itu baru para wisatawan akan berbelanja barang yang diinginkan, sehingga terkadang pendapatan pedagang pasar yang ada di belakang lebih banyak daripada yang berada di area depan pasar. Hal ini bertolak belakang dengan hasil penelitian yang didapatkan oleh Artaman (2015) dan Atun (2016), yang menyatakan bahwa lokasi usaha berpengaruh terhadap tingkat pendapatan pedagang pasar.

Hasil nilai t hitung untuk variabel parkir $\left(\mathrm{X}_{5}\right)$ adalah 1,565 dengan nilai signifikansi sebesar 0,122 berada di atas nilai taraf 0,05. Artinya, parkir tidak dapat mempengaruhi pendapatan pedagang pasar. Sehingga, hipotesis kelima $\left(\mathrm{H}_{5}\right)$ yaitu Parkir berpengaruh positif terhadap pendapatan pedagang Pasar Seni Guwang tidak diterima. Sehingga, hasil uji hipotesis ini tidak dapat memperkuat penelitian dari Artaman (2015) yang menunjukkan bahwa variabel parkir berpengaruh signifikan terhadap pendapatan pedagang. Para pedagang pasar seni guwang merasakan bahwa parkir yang luas dan nyaman tidak dapat mempengaruhi peningkatan pendapatannya dikarenakan para pelanggan yang datang kebanyakan merupakan 
wisatawan yang menggunaka jasa travel atau menggunakan bus, sehingga posisi parkir sudah ada yang mengatur, dan tidak akan mempengaruhi pendapatan yang diperoleh para pedagang.

Nilai t-hitung Penyuluhan dan Pelatihan $\left(\mathrm{X}_{6}\right)$ sebesar -0,077 dengan nilai signifikansi sebesar 0,939. Artinya, penyuluhan dan pelatihan tidak dapat berpengaruh positif terhadap pendapatan pedagang Pasar Seni Guwang. Sehingga, hipotesis keenam $\left(\mathrm{H}_{6}\right)$ yaitu Penyuluhan dan pelatihan berpengaruh positif terhadap pendapatan pedagang Pasar Seni Guwang ditolak. Rata-rata para pedagang sudah dapat berkomunikasi sederhana dengan para wisatawan, sehingga penyuluhan maupun pelatihan yang diberikan dirasa tidak akan dapat mempengaruhi pendapatan yang diterima oleh para pedagang Pasar Seni Guwang.

\section{SIMPULAN DAN SARAN}

Adapun kesimpulan yang dapat disusun berdasarkan hasil dan pembahasan penelitian tersebut, yaitu: (1) modal usaha berpengaruh signifikan terhadap pendapatan pedagang Pasar Seni Guwang. (2) lama usaha, jam kerja, lokasi usaha, parkir dan Penyuluhan dan Pelatihan tidak berpengaruh secara parsial terhadap pendapatan pedagang Pasar Seni Guwang.

Saran yang dapat diberikan pada penelitian selanjutnya adalah: (1) penelitian ini hanya menggunakan sampel sebanyak 84 orang, sekiranya penelitian selanjutnya dapat menambah jumlah sampel penelitian. (2) penelitian ini hanya dapat membuktikan satu variabel yang berpengaruh yaitu modal usaha, sehingga diharapkan penelitian selanjutnya dapat menggunakan variabel lain yang dapat menjelaskan pengaruh pendapatan pedagang. (3) penelitian ini hanya menggunakan satu lokasi penelitian, sehingga terbatas pada lokasi penelitian. Penelitian selanjutnya diharapkan menggunakan lebih dari satu lokasi penelitian sehingga dapat menciptakan generalisasi penelitian. 
Widya Akuntansi dan Keuangan

Universitas Hindu Indonesia

Edisi Agustus 2019, ISSN 2655-9498

\section{DAFTAR PUSTAKA}

Artaman, Dewa Made Aris. 2015. Analisis Faktor-Faktor yang Mempengaruhi Pendapatan Pedagang Pasar Seni Sukawati di Kabupaten Gianyar. Tesis.Universitas Udayana

Asmie, Poniwati. 2008. Analisis Faktor-faktor Yang Mempengaruhi Tingkat Pendapatan Pedagang Pasar Tradisional Di Kota Yogyakarta. Tesis. Universitas Gajah Mada Yogyakarta.

Atun, Nur Isni. 2016. Pengaruh Modal, Lokasi, dan Jenis Dagangan terhadap Pendapatan Pedagang Pasar Prambanan Kabupaten Sleman. Skripsi. Universitas Negeri Yogyakarta.

Balipost,2013.Pengerajin Kini Mati Suri.Edisitanggal 16 agustus 2013.Hal.3

Dirlanudin. "Paradigma Baru Pengembangan Usaha Kecil." Jurnal Ilmiah Niagara1, no. 2 (2008): 47-67.

Firdausa, Rosetyadi Artistyan. 2012. Pengaruh Modal Awal, Lama Usaha dan Jam Kerja terhadap Pendapatan Pedagang Kios di Pasar Bintoro Demak. Skripsi. Universitas Diponegoro Semarang

Ghozali, Imam., M.Com., Ak,. 2012. Aplikasi Analisis Multivariat dengan Program SPSS. Cetakan IV. Badan Penerbit Universitas Diponogoro. Semarang

Kantor Administrasi Pasar Seni Guwang Sukawati Kabupaten Gianyar. 2017. Data Jumlah Kedatangan Bus dan Wisatawan Pasar Seni Guwang Sukawati Kabupaten Gianyar.

Nama, Artawa. 2012, Pasar Seni Sukawati Orientasi Sekolah Tinggi Pariwisata Nusa Dua,Dinas Pendapatan Kabupaten Gianyar.

Putra, Gde Bagus Brahma Putra dan Yuliastuti, Ida Ayu Nyoman. 2019. Kemampuan Menghasilkan Keuntugan Usaha Mikro Kecil Menengah di Kota Denpasar dan Faktor-Faktor yang Mempengaruhinya. Jurnal Riset Akuntansi. Vol. 9. No. 1. Hal 3747

Stice ,Earl K Stice, James D and Skaousen, K. Fred. 2011. Intermediate Accounting, Edisi ke 15,Cetakan Pertama diterjemahkan oleh Palupi Wariati,Penerbit : Palupi Wariati, Salemba Empat, Jakarta.

Sugiyono. 2013. Metode Penelitian Bisnis. Cetakan Enam belas. CVAlfabeta. Bandung

Suparmoko, 1990.Pengantor Ekonomi Mikro, Edisi Pertama BPFE Yogyakarta.

Sutrisno Hadi. 2007. Analisis Regresi. Yogyakarta: Andi Offset 
Widya Akuntansi dan Keuangan

Universitas Hindu Indonesia

Edisi Agustus 2019, ISSN 2655-9498

Wahyudi, Nur Rahmad. 2010. Analisis faktor-faktor yang mempengaruhi Pendapatan pedagang pasar tradisional Di kabupaten sukoharjo (studi kasus di pasar nguter kecamatan nguter). Skripsi. Universitas Sebelas Maret Surakarta

Wirautama. 2012. Tourism Field Study 2012: Tradisional vs Modern Dalam Pengelolaan Pasar seni.

Vera Laksmi Dewi, Anak Agung Ayu, 2012. Faktor-faktor yang mempengaruhi Pendapatan Pedagang Canang di Kabupaten Badung. Jurnal Piramida.7 (1) available at: ejournal.unud.ac.id/

Widya Utama, I Gst Bagus Adi, 2012. "Faktor-faktor yang mempengaruhi Pendapatan Pengusaha Perak di Desa Celuk Kecamatan Sukawati Kabupaten Gianyar" (tesis). Denpasar : Universitas Udayana.

Yuliastuti, Ida Ayu Nyoman dan Dewi, Ni Luh Putu Sandrya. 2017. Analisis Efektivitas dan Kontribusi Retribusi Daerah terhadap Pendapatan Asli Daerah (PAD) Kota Denpasar. Jurnal Riset Akuntansi. Vol 7. No. 1. Hal 91-102

Yusuf Yusbar dkk.,2010. Implikasi Program Nasional Pemberdayaan Masyarakat (PNPM) Mandiri Pedesaan Terhadap Pendapatan Pedagang Kecil Di Kecamatan Langgam Kabupaten Pelalawan Propinsi Riau Tahun 2007-2010. Journal of Economics. Fakultas Ekonomi Universitas Riau 